\title{
AUTOMATION: A NEW MANAGEMENT PROBLEM
}

Beschouwingen naar aanleiding van een praeadvies van J. Diebold voor het C.I.O.S.-congres.

\author{
door Ir.F. G. Willemze
}

Dit is het eigenlijke thema van het voortreffelijke praeadvies van de bekende Amerikaanse deskundige J. Diebold voor het Xle Congres International de l'Organisation Scientifique (C.I.O.S.), waarvan de behandeling op verzoek van de redactie hier zal worden besproken. Dit congres, dat van 24-28 juni 1957 in Parijs gehouden werd en waaraan ca. 1300 personen van over de gehele wereld deelnamen, stond in het teken van:

"Concrete archievements of enterprises and other bodies in the field of scientific management. Future prospects in the light of technical and social developments".

Het is dan ook begrijpelijk dat "Automation" (The development of automation in industry; J. Diebold) en .,Operational Research (Scientific preparation for decisions; M. L. Hurni) tot de onderwerpen behoorden, die de meeste aandacht trokken. Hiertoe mag echter zeker ook gerekend worden de bijdrage van Prof. Dr. F. L. Polak (Directeur Centraal Plan Bureau): ,The problems of maintaining continuous and full employment" en dat misschien beter gekarakteriseerd kan worden door: de invloed van de automatisering op de werkgelegenheid. Deze bijdrage lokte speciaal van Amerikaanse zijde felle reacties uit (de bekende Peter Drucker was opponent). Hoewel de vraag van de redactie zich bepaalde tot het bespreken van de bijdrage van Diebold, zijn bovenstaande praeadviezen vermeld om vooral de aandacht te vestigen op de General Reports van dit congres, dat deze en nog meer zeer goede bijdragen op het gebied van het „scientifique management" bevat 1 ).

Begrijpelijk in dit gezelschap, maar ook volkomen terecht, werd het automatiseren door Diebold niet als een technisch maar als een management probleem gesteld. Deze kant is tot nu toe te veel verwaarloosd, men heeft zich te eenzijdig op de machine en de apparatuur gericht, ook op besprekingen en conferenties, in boeken en tijdschriftartikelen. Hierbij werd dan steeds veel aandacht besteed aan het definieren van ,,automation", uitgaande van de machines en de ontwikkeling daarin. Maar hoe fascinerend deze machines ook zijn, zij zijn niet het essentiële. Het essentiële is de nieuwe wijze van het benaderen der problemen. (die nu, dankzij deze ontwikkeling in de geautomatiseerde machines, wordt mogelijk gemaakt) n.1.: het „organiseren" van handelingen en verrichtingen in kantoor en fabriek in complete systemen 2 ), het beheersen van deze systemen en het zelfregelend maken van dergelijke systemen.

Sinds het ontstaan van het woord ,,automation" is er veel over geschreven en gefantaseerd, wat geleid heeft tot bepaalde gedachtengangen, die men als axioma's is gaan hanteren. ,The danger is not having push-button machines, but in being content with a push-button type of thinking". Met een viertal van de meest voorkomende tracht Diebold af te rekenen.

1) General reports XIe International Congres of Scientific Management. Uitgave van "Comité National de l'organisation Française", 5 Rue de Babylone, Paris.

2) Onder systemen wordt hier verstaan: het geheel van handelingen of bewerkingen dat noodzakelijk is om een volledige procedure tot stand te brengen. 
1. Automation is slechts toepasbaar in zeer kapitaalkrachtige bedrijuen en bij produktie in zeer lange series. Deze gedachtengang is heel goed te begrijpen daar het begrip oorspronkelijk ontstaan is in de automobiel industrie en ook in de administratieve sector de eerste toepassingen op het gebied van de zeer vele gelijksoortige handelingen lagen. De laatste tijd komen er echter steeds meer automatische machines waarbij de voorbereiding buiten de machine en zeer snel kan geschieden, zodat zij reeds bij kleine series en zelfs bij enkelfabricage geschikt zouden zijn. Dikwijls wordt het fabriceren van vele verschillende typen gebruikt als argument tegen de toepassing van de automatiseringsgedachte in een bedrijf. Bij analyse blijkt dan echter veelal dat $80 \%$ van de produktie slechts enkele typen betreft waarop het zonder meer nuttig is de bovengenoemde probleembenadering toe te passen. Deze behoeft dan niet direct te leiden tot een volautomatische machine met terugkoppeling en al die fantastisch push-button-fabriekachtige dingen. Soms is het gevolg alleen maar, het in lijn opstellen van machines en misschien het koppelen door eenvoudige transporteurs. Dus het meer "systematisch" opstellen van de produktiemiddelen. Dit kan dan een eerste stap zijn naar automatisering van de produktie.

2. Het summum van automatisering is de olieraffinaderij. Inderdaad heeft men daar de fabricage van een partijgewijze produktie in een continu proces weten om te zetten, wat de automatisering vergemakkelijkt. Maar van een zelfregelend proces is nog in het geheel geen sprake. Wel kunnen dankzij ingenieuze mechanismen, belangrijke grootheden binnen nauwe grenzen aan een gegeven waarde gehouden worden, indien aan bepaalde voorwaarden - o.a. van grondstoffen - is voldaan, maar de keuze van deze waarden moet telkens weer door de machinebediende worden uitgevoerd. Ditzelfde geldt voor allerlei andere chemische en mechanische processen. Het is dus de machinebediende, die bij deze gecompliceerde apparatuur de verschillende waarden moet kiezen om het geheel zo effectief mogelijk te laten verlopen. Dit is in vele gevallen meer geluk dan wijsheid. Volgens Diebold heeft dit tot gevolg dat de opbrengst in dergelijke gevallen gemiddeld $30 \%$ of meer afwijkt van wat maximaal verwacht kan worden. Dit is dus het gevolg van het feit dat men het verband tussen de verschillende factoren en hun invloed op het eindresultaat niet voldoende kent om ze voor het zelfregelen te gebruiken. Is dit eenmaal bekend, dan zal door middel van computers deze zelfregeling tot stand kunnen worden gebracht. Het is echter steeds te overwegen of al de tijdrovende research om deze relaties te leren kennen en de kostbare apparatuur uiteindelijk lonend zijn. De gedachtengang die er aan ten grondslag ligt kan echter steeds met vrucht worden toegepast.

In de administratieve sector is men wat apparatuur betreft aanzienlijk verder dan in de technische sector. Het is daar niet noodzakelijk op steeds nieuwe machines te wachten. Volgens een onderzoek van Diebolds firma zijn practisch alle computers in Amerika kwantitatief en kwalitatief onderbezet. Wat ontbreekt is juist het principiële denken in systemen dat noodzakelijk is om los te komen van de gebruikelijke administratieve behandeling en te komen tot de essentiële te verrichten procedures. Dat is ook hetgeen waarom bijv. in Nederland de laatste tijd pogingen in het werk gesteld worden om systeem-analytici op te leiden.

3. Automatisering is in de eerste plaats geschikt om arbeid te besparen. Indien men het praeadvies van Prof. Polak bestudeert en zijn toelichting 
gevolgd heeft, krijgt men inderdaad zeer sterk de indruk dat het uiteindelijke resultaat van deze automatisering slechts werkvermindering en werkloosheid kan zijn. Dat zou onvermijdelijk zijn en er kan slechts iets aan gedaan worden om de ergste gevolgen te verzachten, bijv. door regeling van overheidszijde. Drucker is hier zeer nadrukkelijk tegen in het veld getreden, waarbij hoewel niet zo uitgesproken, toch steeds merkbaar is: „Waar praat men in Europa eigenlijk over, wij Amerikanen zijn de enige die ervaring op dit gebied hebben en voorlopig hebben we nog slechts een groot tekort aan mensen wat de automatisering eerder stuwt dan andersom." Dit lijkt een redenering op kort zicht, vooral als men het argument van Polak in rekening brengt. Deze stelt dat inderdaad nog steeds alle overcomplete arbeidskracht opgevangen kan worden in de dienstensector, omdat deze zo uitermate inefficient werkt, maar dat ook daar eens de rationalisatie zal doordringen. Toch wordt wel over het hoofd gezien dat vele automatiseringsprocessen niet in de eerste plaats ten doel hebben mensen te besparen, maar dingen te doen die anders eenvoudig weg onmogelijk zouden zijn, terwijl er voorts allerlei arbeid is die men tegenwoordig niet meer menswaardig acht en daarom reeds gemechaniseerd of geautomatiseerd moet worden.

Als voorbeelden van het eerste kunnen genoemd worden de steeds hoger wordende nauwkeurigheidseisen op allerlei arbeid.

Voorts stellen bijv. moderne computers in staat in het kader van operational research met een zodanige snelheid gegevens te verschaffen, dat op het ogenblik van beslissen dit mede op grond van nauwkeurige analyses kan geschieden in plaats van alleen op intuïtie. Een speciaal voorbeeld daarvan is het toepassen van de z.g. Monte-Carlo-methode, waarbij (indien het ,,model" bekend is) de resultaten van een groot aantal mogelijke beslissingen zeer snel kunnen worden verkregen en waaruit de optimale beslissing kan worden gezocht.

Indien men automation (en dan misschien speciaal de computer) alleen ziet als arbeidbesparend hulpmiddel, ziet men dus de mogelijkheden over het hoofd om dingen te doen die anders niet mogelijk zijn in het bijzonder op het gebied van beslissingsvoorbereiding.

4. Daat automatisering zeer technisch is moet het aan technici worden overgelaten. De automatiseringsapparatuur is inderdaad zeer technisch. maar niemand verwacht van de leiding van bedrijven dat zij computers zal bouwen, repareren of programmeren. Dat is het werk van technici en specialisten. De leiding van een bedrijf heeft echter een eigen taak, die minstens even gecompliceerd en moeilijk is. Om werkelijk goede resultaten met ,,data processing apparatuur" te verkrijgen is een fundamentele verandering in aanpak vereist. Bovendien begrip ervoor dat de beste toepassingen niet het resultaat zijn van mechanisatie en stroomlijning van de bestaande procedures, maar van de bereidheid de problemen rondom het gehele bedrijf tot op zijn uiteindelijke doelstellingen opnieuw te willen doordenken. Dit zijn problemen van werkwijze, organisatie en mentaliteit en $z i j$ vereisen visie, scholing en ervaring die meer die van een ,,manager" is dan van een technicus.

Maar in plaats zich dit te realiseren, laat de leiding zich meestal intimideren door de technische gecompliceerdheid waardoor zij niet alleen de technische problemen der apparatuur, maar ook de beslissingen, waarvoor deze apparatuur gebruikt zal worden, aan technici over laat.

Meer dan in één van de voorgaande punten komt hier het thema 
„Automation a new management problem" naar voren.

Met het installeren van geautomatiseerde apparatuur behoort gewacht te worden tot zeer duidelijk uit een organisatie-onderzoek (ev. systeem analyse) is gebleken dat zij noodzakelijk is. Voor een dergelijk onderzoek worden enkele aanwijzingen gegeven.

a. Gewaarschuwd wordt tegen de voorzichtig lijkende „step by step"methode. Bedoeld is hier dat het gevaarlijk is verschillende opvolgende fasen in het totale proces afzonderlijk te bekijken en eventueel één voor één te gaan automatiseren. Tijdens de discussie leek hierover verschil van opinie te bestaan, wat echter uiteindelijk resulteerde in een welkome aanvulling: tijdens het vooronderzoek moeten zo veel mogelijk fasen als één geheel behandeld en samenhangend onderzocht worden, opdat later niet automatisering van een volgende fase door die van een voorgaande wordt tegengewerkt. Heeft echter dit onderzoek plaats gehad. dan is het nuttig om na te gaan tot welke graad geautomatiseerd zal worden, daar vaak de capaciteit (aan geldmiddelen, technici, werkplaatsen e.d.) beperkt is en gedeeltelijke automatisering van enkele projecten vaak even veel kost maar veel meer oplevert dan volledige automatisering van één enkel project. Dit is slechts mogelijk indien men van te voren goed zijn doeleinden stelt en daarop het onderzoek richt. Een dergelijk nauwgezet onderzoek is ook noodzakelijk om na te gaan of de oorspronkelijke redenen voor automatisering wel de werkelijke zijn of dat zij slechts symptonen zijn van dieper liggende problemen, waarbij het dan de vraag is of deze door automatiseren kunnen worden opgelost.

Steeds moet in gedachten gehouden worden dat het gaat om de functie (van produkt, proces, administratie) en niet om de bestaande realisering, die natuurlijk aangepast is aan de huidige mogelijkheden. Vaak wordt dit verward en wordt vanzelfsprekend de huidige werkwijze als principieel aangenomen. Het is ook moeilijk daardoor heen te zien.

b. Daarom is het zo noodzakelijk de juiste man voor het automatiseringsprogramma te kiezen. Dit is niet in de eerste plaats een electronicus of automatiseringsdeskundige, maar een man die het bedrijf door en door kent, op de hoogte is van analysemethoden en enige kennis heeft van de vereiste apparatuur.

,We are satisfied that the way to put together a team of people to work on electronics is to take somebody who has good knowledge of how to run your business, a good systems and procedures man, if you please. They can be trained in electronics much easier than somebody who knows electronics can be trained in how to run your business". "It is not enough to realize that an automation program is best run by choosing a man who understands your business, rather than by an engineer who understands automation equipment. It is of crucial importance to choose the very best man you can find to head up your program". Een onderzoek in verband met automatisering vereist immers een studie van het eigen bedrijf en van de mogelijkheden van automatisering waarvan de gevolgen zo ingrijpend kunnen zijn dat zij het uiteindelijk lot van het bedrijf zelf kunnen bepalen.

c. Het is een probleem op zich zelf van te voren kosten en besparing te berekenen. Het is wel zeer noodzakelijk dit te doen daar de aanloop- en inleerkosten vaak enorm hoog zijn. „Een computer kost het dubbele 
van wat hij kost". Het is daarom dan ook, dat geadviseerd wordt als eerste object niet salarisadministratie e.d. te nemen, maar te zoeken naar zodanige systemen, die naast directe besparingen als bijprodukt informatie geven, die het voeren van de leiding vereenvoudigen, dus niet calculeerbare voordelen verschaffen, die op andere wijze onmogelijk waren te verkrijgen.

d. Automatisering is in hoge mate een trainings- en vormingsprobleem. Het opleiden voor het bedienen, programmeren en onderhouden van de apparatuur, het opvoeden voor de nieuwe wijze van werken - waarbij de „zwoegers" zullen zijn vervangen door „,schakelbord wachters", de handenarbeid door ogen- en eenvoudig hersenwerk - doet opnieuw een beroep op de leiding. Het is noodzakelijk om eigen mensen hiervoor te bekwamen, daar zij niet van buiten te betrekken zullen zijn en het bovendien voor het bedrijf aantrekkelijk is eigen mensen te houden. Het is echter niet alleen vermeerdering van technische kennis wat is vereist. .Automation not only presents management with a training problem. Education in the widest possible sense, is the most urgent problem of automation".

"Management must learn new skills, it is true, but these skills are uniquely managerial and call for the best effort that we can all give to the problem of trying to define the qualities that are needed for succesfull management in an age of automation and then to learn how we can both acquire and teach these skills. This problem is the fundamental problem automation poses for management". 